\title{
Local authorities as niche actors: the case of energy governance in the UK
}

Article

Accepted Version

Fudge, S., Peters, M. and Woodman, B. (2016) Local authorities as niche actors: the case of energy governance in the UK. Environmental Innovation and Societal Transitions, 18 (1). pp. 1-17. ISSN 2210-4224 doi:

https://doi.org/10.1016/j.eist.2015.06.004 Available at https://centaur.reading.ac.uk/57619/

It is advisable to refer to the publisher's version if you intend to cite from the work. See Guidance on citing.

Published version at: http://www.journals.elsevier.com/environmental-innovation-and-societal-transitions/

To link to this article DOI: http://dx.doi.org/10.1016/j.eist.2015.06.004

Publisher: Elsevier

All outputs in CentAUR are protected by Intellectual Property Rights law, including copyright law. Copyright and IPR is retained by the creators or other copyright holders. Terms and conditions for use of this material are defined in the End User Agreement.

\section{www.reading.ac.uk/centaur}

\section{CentAUR}

Central Archive at the University of Reading 
Reading's research outputs online 


\section{Local authorities as niche actors: the case of energy governance in the UK}

Shane Fudge, Department of Geography, College of Life and Environmental Sciences, Penryn Campus, Cornwall TR10 9FE, UK

Michael Peters, School of Construction Management and Engineering, Whiteknights, University of Reading, RG66UR, UK

Bridget Woodman, Energy Policy Group, University of Exeter Cornwall Campus, Treliever Road, Penryn, Cornwall TR10 9EZ, UK

\section{Introduction}

Whilst growing evidence from the Intergovernmental Panel on Climate Change (IPCC, 2013) on the causes and consequences of climate change has meant that there is increasing urgency for political action on sustainability, effective policy initiatives must address the problem of changing or transforming complex systems of production and consumption, and economic, political and social 'lock in' (Unruh, 2000). The fact that this transition implies the involvement of multiple actors and institutions, whilst simultaneously addressing a variety of different issues, values and worldviews, means that there is clearly no single point of intervention that will be effective in dealing with the problem of sustainability in isolation.

Organizing action, influence and change from the local level has become a core focus for the encouragement of sustainability pathways and processes by a range of stakeholders and decision makers. This perspective gained momentum from the time of the Rio Earth Summit in 1992, when Local Agenda 21 became the first substantive political programme to actively encourage grassroots level action to be incorporated more fully into both national and local policy frameworks on sustainability (Fudge and Peters, 2009). The appearance of Local Agenda 21 itself signified an increased acknowledgement that sustainability is a 'wicked issue' which requires a much more nuanced and broad ranging approach than traditional top-down policy measures are likely to deliver. Whilst conventional policy agendas around environmental pollution have traditionally evolved around 'end of pipe' solutions, as Fudge and Peters (2009) have suggested, the growing impetus around sustainable energy for instance, now includes 'an increasing consensus amongst policy-makers that projects which can be "embedded" within bottom-up social, cultural, and economic particularities hold the potential to be more effective than top-down solutions in enabling individuals to recognize their own role in contributing to more sustainable levels of energy consumption and also in encouraging citizens to engage more fully in the wider political debate on sustainable living' (Fudge and Peters, 2009: 34). A range of similar studies concerning local authorities and their role as intermediary agents confirm these points of interest and demonstrate the relevance of UK local government activities in this area in a broader European context (e.g. Späth and Rohracher (2010); Hodson and Marvin (2012); Bulkeley and Kern (2006)).

The role of local government has been seen as critical to this agenda and is identifiably a key medium through which to coordinate and influence workable local level responses to the problem of developing more effective policies around energy and environmental issues. In the 
UK for example, the 2012 Committee on Climate Change Report How Local Authorities Can Reduce Emissions and Manage Climate Change (CCC, 2012) makes particular reference, for example, to the role of local authorities in providing an effective local interface between technological innovation and diffusion, business practice, institutional change, and broader community and individual behavioural change. More recently, whilst the introduction of a Feed in Tariff, a Renewable Heat Incentive, and proposed roll out of Smart Metering in homes, is likely to encourage new entrants and innovations in the energy supply market (Fudge et al, 2012), unless the technology choices in this pathway are accompanied by associated levels of social and institutional learning, and due consideration is given to social acceptability and consumer engagement, they are likely to fall short of expectations. It is clear that the transition to a low carbon economy will involve a 'step-shift' in the beliefs, values and ideals held by citizens in respect of the kind of society that is ultimately desired. This will require greater political will to act, which will inevitably involve making some hard choices in relation to overhauling current systems of production and consumption, decision-making processes, and institutional arrangements.

\subsection{Aims of this paper}

The paper sets out to explore the influence and changing position of local government in relation to energy and environmental issues, through an exploration of six local authorities and different ways in which they have been able to influence the governance of energy in the UK by developing or instigating their own indigenous low carbon programmes. Through a combination of literature review and empirical research, the paper suggests that, in recent years the UK has witnessed a shifting regulatory regime around energy, part of which has been instigated through the actions of local government. It is that argued that the low carbon agenda in the UK has provided a 'window of opportunity' for some of the more progressive of them, suggesting that local authorities are likely to exert greater influence over the future direction of energy policy in the UK. The paper provides fresh insights into the Multi-Level Perspective (MLP) conceptual framework in the context of these issues expanding on observations made by Seyfang et al (2014: 24), who argue that: 'the niche-regime model in the Multi-Level Perspective simplifies a complex plurality of socio-technical configurations (i.e. the role and influence of community-led initiatives) into unrealistically homogenous niches working against similarly problematic conceptualizations of a homogenous regime'. The work of writers such as Dixon and Wilson (2013) looking at 'cities as individual innovators' has begun to move the literature in this direction and, to this end, we seek to address the general omission of the role of local authorities in the extant MLP literature, suggesting that the role of energy and sustainability provides a pertinent framework though which to assess ways in which local government has become more influential in redrawing system boundaries and opening up 'windows of political opportunity', particularly in relation to current understandings of both regime and niche level configurations.

\section{Materials and methods}

The paper itself draws on qualitative data gathered through the administration of a series of semi-structured interviews with a small number of English local authorities between May and September 2012. In total 18 interviews were carried out involving representatives from Bradford Metropolitan District Council, Woking Borough Council, Oxford City Council, Surrey County Council, Kirklees District Council, and Rhondda Cynon Taff County Borough Council. One additional interview was carried out with a representative from the Energy Saving Trust, a non- 
profit organization jointly funded by the British Government and the private sector (please see Table 1 at the end of the paper for participant details). In each case, interviewees included senior officers who are active in both environment and energy decision making across a range of departments in order to identify the scope and extent of priorities and different perspectives that are apparent within and between the participating local authorities.

In UK policy circles there is a growing recognition that the kind of interface between policy making, market-led technological innovation, and the public which is likely to deliver current and future carbon reduction targets, can perhaps be provided through the efforts of local authorities; building on their existing geographical and political proximity to individual, household and community level activities and practices. During this research therefore, the influence of local authorities on energy and environmental issues were explored in relation to the following three areas:

1. 'Window of political opportunity": where the role of local government has been able to exert greater influence over energy, within the context of evolving national and international policy frameworks and has consequently become more influential in decision-making on energy and environmental issues;

2. 'Community Engagement': considering the ways in which local government are able to engage or incorporate the public into their strategies for sustainable energy policy (behavioural niches);

3. 'Technology and technological innovation': examining the ways in which local authorities have been able to evolve as 'niches' around technologically driven pathway solutions in relation to sustainable energy management.

The work was conducted under the NERC-funded project 'Understanding energy governance at local and community levels' - a 24 month study carried out in collaboration with the UK Energy Research Council which began in April 2010. The particular work-package in which these interviews were located (entitled 'Local government in energy governance') concentrated on the institutional structure of local governance and how external forces and actors influence local authorities on their decision making and practices vis-à-vis energy issues.

\section{Theory}

\subsection{The role of local authorities in a sustainable energy transition}

Whilst there is a wealth of literature on the role and potential role of communities in influencing energy and environmental issues at the local level (e.g. Devine-Wright, 2011; Peters et al., 2010; Walker and Devine-Wright, 2008), the role and influence of local authorities in the sustainable energy transition has often been either underplayed or they have been viewed as a part of the 'dominant regime'; often counter-posed to the niche activities of community groups and organizations (Bolton and Foxon, 2013; Bulkeley et al, 2011). This is perhaps a key debate in relation to the role and potential influence of local authorities in a UK energy transition more broadly. In other words, is it possible to argue that local authorities are influencing a new governing/political regime, characterised by challenges to current 'system boundaries' around energy and environmental issues? Whilst local authorities originally had a huge influence over the UKs' localized town gas infrastructure, from the time of the post-war period, they were then marginalized by the UK Government and consequently had minimal input to the country's primarily centralized energy system - both state managed and market led. 
This situation has begun to change again in recent years however with energy and environmental matters increasingly 'spilling over' into a number of existing local government duties and responsibilities. In fact, the influence of some of the more 'progressive' local authorities - such as Woking, Kirklees, Leicester and Southampton - suggests that they might even be considered as 'turn-keys' on these issues in their geographical areas of jurisdiction. In other words, the increasing influence of 'landscape' concerns around energy and environmental challenges on national level policy making has been taken up by these local authorities and has enabled them to exert a measure of influence in challenging or transforming existing patterns of energy decision-making and practices. The work of McGuirk et al (2015) has explored this scenario in Australia, where they suggest that local government initiatives on climate and carbon have come to the fore as government 'experiments'. Energy security, climate change and energy affordability have been particular problems for mainstream policy makers - not least due to their trans-national, 'wicked' nature. The fact that these are all issues that do not fit easily into mainstream policy frameworks has offered local authorities the possibility to shape, inform and influence bottom-up solutions around both energy supply systems and also in demand reduction/management.

Walker and Devine-Wright (2008: 497) have observed the increasing significance of local energy supply and use, making the particular point that the increasing possibilities for electricity and heat generated through micro and community scale generation, 'may suggest a significant change in UK energy policy away from focusing on the large-scale, centralized technical systems devised to generate and supply energy in the mid to late 20th century'. To this end Jackson (2005) argues that an effective policy framework should be characterized by a judicious combination of technological innovation and the way in which this is likely to interact and engage with local social and cultural terrains, encouraging the emergence of more 'place-based' energy infrastructures. In the UK, for example, the practical difficulties of reaching increasingly stringent targets on $\mathrm{CO}_{2}$ emissions have encouraged policy-makers to work more closely not only with more local means of energy supply, but also with changes that target the role of individuals and communities.

As argued above, this has largely resulted from a political acknowledgement of the growing complexities of how to develop practical sustainability measures which 'buy-in' to their social and environmental surroundings. Significantly, policy-makers have been forced to acknowledge that structural changes encouraged by energy privatization have been eroded, necessitating a shift in emphasis towards a more consumption based policy strategy; one which would more effectively deal with the growth and increase in road and air travel (Royal Commission, 2000) and also with the primacy of behavioural and social norms which give rise to increased energy demand in housing and buildings (CCC, 2013).

\subsection{Theorizing change: what is a sustainable transition?}

Mulugetta et al (2010) have pointed out that the move towards a more sustainable society will be complex and non-linear, and that there is no single point of intervention which will be effective on its own. Whilst theories around socio-technical transitions take this premise as a starting point, Haxeltine and Seyfang point out that the Multi-level Perspective can offer an effective 'governing framework' and a practical model for understanding the 'co-evolution of actors, institutions and technologies in the reproduction and transformation of large 
infrastructural systems such as energy supply' (Bolton and Foxon, 2013: 2195). Importantly, they suggest that:

Understanding transition is especially important when dominant 'solutions' (and the socio-technical systems that deliver these) contribute to unsustainable development and when novel solutions might offer more sustainable alternatives, or when we face persistent problems that can't be solved using only the currently dominant solutions. In the context of debates about sustainability, we are interested in understanding the processes and patterns of competition among established and novel solutions to questions of production and consumption. We are interested in how novel and radical solutions emerge (as socio-technical 'niches') and become sufficiently powerful to challenge and, ultimately, overthrow a dominant solution (the prevailing 'regime' of production and consumption, including the associated practices and set of actors) resulting in a transition (Haxeltine and Seyfang, 2009: 3).

For many of the theorists working under this banner, including Bolton and Foxon (2013), Geels (2002; 2010), Loorbach (2007), and Scrase and MacKerron (2009), urban energy infrastructures represent technical systems of complexity that are influenced by a range of non-technical as well as technical factors. These include institutional changes, user practices, prevailing policy and regulation, technological innovations, ecosystem change and business strategies. As Calvert and Mabee (2014) have argued, this ontological and epistemological framing of 'transition' poses particular challenges for the ways in which energy and sustainability are currently understood in terms of neo-liberal, market based outcomes where, in relation to the viability of renewable energy for instance, they point out that:

The social and environmental imperatives to replace non-renewable with renewable energy (RE) resources are strong, and the technological means by which to achieve this goal are available and improving. The problem however, is that a systemic and selfreferential preference for fossil energy resources has been deeply entrenched within social and political-economic activities as well as their underlying institutional and physical structures over the last three centuries (Calvert and Mabee, 2014: 2)

The complexity issue noted above has clear relevance in respect of sustainable energy, with the transitions themselves being multi-faceted and complex, involving a wide range of stakeholders including decision-makers, practitioners and end-users. Transition Theory - and in particular Multi-Level Perspective (MLP) - provides an imaginative and objective platform from which to assess, appraise and gain a better understanding of transitions to the realisation of sustainable energy systems and the replacement of embedded socio-technical practices by radical innovations (Geels, 2002; Geels, 2010). In the following section we consider MLP in more depth.

\subsection{The Multi-Level Perspective}

Utilized in the transitions literature as a heuristic device for framing the complexities of change, the Multi-Level Perspective (MLP) emerged from the literature around what should be posited as the salient characteristics of 'transition'; placing more of an emphasis on how changes unfold over time (Raven et al, 2012: 67). MLP conceptualizes society through a series of interlinked levels, or domains, with interaction and 'friction' between them providing the predominant 
impetus for infrastructural change (Bolton and Foxon, 2013). The levels outlined in MLP can be defined as follows:

- Landscape (macro level) - this level relates to the overall setting by which political beliefs and worldviews, the dominant social and cultural values, and the institutional elements of society set the framework for the 'lifeworld'. The landscape level encompasses the wider set of factors "...which shape and contextualise activities within niches and regimes" (Bolton and Foxon, 2013: p.2196). For instance, the current policy landscape is underpinned primarily by the principles of the market, meaning that the 'higher order' values, beliefs, and worldviews will be largely influenced by the economy, globalization, rules around trade, costs, prices etc. The landscape is the more 'structurally based' element of the lifeworld, and change here is likely to happen much more slowly than in the other two arenas.

- Regime (meso level) - this is the level at which the contextual setting of the landscape outlined above is articulated into being by particular actors, groups and alliances. In much of the transition literature, this domain relates in particular to the influence of socio-technical systems. The regime is the level at which these systems are made manifest through the dominant practices, institutional arrangements and technologies that are 'aligned to each other and coordinated' (Geels, 2002:1259).

- Niche (micro level) - this level refers to spaces of radical and innovative possibilities, where the usual market selection processes that take place in the regime do not impinge. Niches can be considered to be the most flexible of the three domains and often catalysts to broader change. In this way, niches are often viewed as developments that are able to challenge mainstream ways of doing things and which offer alternatives to system problems.

Figure 1 explains how theorists working with the MLP try to make sense of societal change through interaction between landscape, regime and niche 


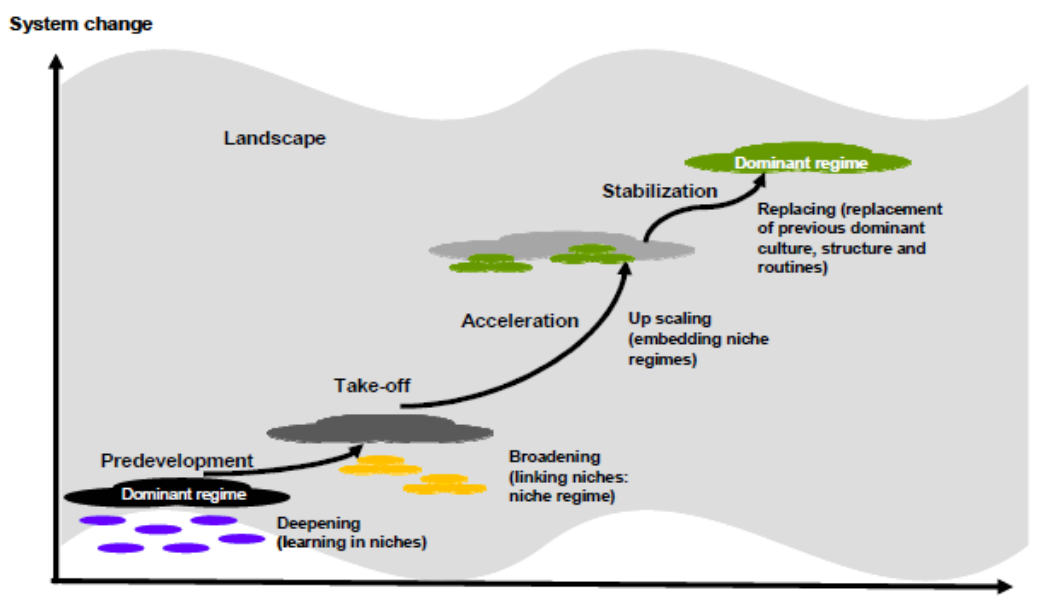

Figure 1: Deepening, broadening and scaling up for changing the regime (Van de Lindt, Emmert and van Sandick, 2009, p.42)

Transforming our energy systems is at the heart of trying to configure sustainable change, and Calvert and Mabee (2014: 1) have argued that MLP provides an excellent theoretical starting point through which to make sense of "the physical properties or 'materialities' of emerging energy resources". They suggest that a more sustainable energy future will emerge around the 'quality, quantity and location of emerging energy resources' and the ways in which these characteristics can be aligned through time and space with existing social, political and economic arrangements. The dynamics of this model provide a particularly useful approach for examining how the regulatory regime governing national energy markets continues to exert influence on the re-configuration and the possibilities for more localised urban energy systems, including the role of local authorities in influencing energy governance in the UK. As Bolton and Foxon (2013) highlight, the MLP literature largely fails to recognise or analyse the agency of niche level activities in the management and regulation of energy. In this paper we provide a contribution to this gap by considering how the increased need for local governance of energy has opened up niche level possibilities for local authorities to exert influence in the governing regime in the UK. As argued above, whilst they have had little influence over the primarily centralized model of energy policy since the post-war period, there are signs that the transition to a low carbon economy has opened up a 'window of opportunity' for innovation and influence; one which has emerged from an interesting interplay around conventional understandings of niche/regime dynamics.

\subsection{Why local authorities?}

\subsubsection{Political influence from the local level}

Whilst there is no consensually agreed pathway in place to meet the UK Government's target of an $80 \%$ reduction in greenhouse gas emissions by 2050 , meeting this and interim targets clearly requires strong, co-coordinated efforts from a variety of different stakeholders. The call for local action in energy relates to both 'institutionally driven' (i.e. local government) initiatives, and also more organic or 'grassroots' approaches such as Transition Towns and other low carbon community initiatives. Reflecting this argument, a range of funding and support schemes has 
become available in the UK for this type of localized, community-based energy agenda, particularly during the last decade. Observing the growing significance of this scale of intervention, and the way in which niche level actions have more recently emerged from the level of local governance, Mulugetta et al (2010:7541) argue that: 'they can make many important indirect contributions in creating the space to evaluate models of social innovation, the platform for nurturing and sharing of technical skills, as well as the marketplace where low carbon options can gain some traction. They can provide new political opportunities for active citizen engagement and challenge dominant discourses in energy'. Fudge and Peters (2009) and Fudge et al (2013) further suggest that the role of local authorities is a vital element of this kind of 'localism', where their formal political status and existing role as local service providers can potentially 'galvanise' a more community based approach to the UK's energy policy agenda.

\subsubsection{Engaging the public}

The possibilities for local authorities to involve the wider community in designing and implementing policies to address climate change has become more of a focus for policy makers, academics and practitioners concerned with the transition to a resilient, low carbon energy future for the UK, particularly during the last $10-15$ years. The Government's 2011 Carbon Plan (HM Government, 2011), for example, repeatedly emphasises the potential agency of local authorities in both these regards, and academic publications such as Peters et al (2010) and Peters et al. (2013) serve to re-iterate the opportunities and challenges for local government in these endeavours. Wade (2008) suggests that local authorities "...can and should lead their local communities in responding to the challenge of climate change. Indeed, sustainable communities can only be shaped successfully if meeting the climate challenge is at the heart of local government's community leadership role. Action to reduce carbon emissions will only happen if people see the link between small, individual actions and the global problem of climate change, and this is where the involvement of local authorities is crucial - especially in terms of emphasising the relevance of collective endeavour (Wade, 2008:29).

\subsubsection{Technology and infrastructure}

On a statutory level, local authority engagement in an emerging energy governance framework now includes a number of projects where electricity and heat functions are channelled through micro and community scale generation. Significantly, in terms of the potential for new forms of political engagement and decision-making, such projects would, in the more recent past, have been constrained by the somewhat limiting powers, finance and cultures of local authorities and their particular relationship to central government objectives. However, already many local authorities in the UK have begun to take on a leading role in making some form of renewable energy supply a pre-condition for any major new development. The recent introduction of guaranteed payments through Feed-In-Tariffs (FITS) and the Renewable Heat Incentive (RHI) for instance, may well be illustrative of local authorities becoming increasingly active in the development of a more decentralized energy system in the UK. Significantly, their current roles as local service providers and decision making fora in relation land, space and planning issues, suggests that local authorities will almost inevitably continue to hold a measure of influence over both the scale and scope of the UK's future energy system.

This argument was given fresh impetus in 2011 with the announcement that local authorities would now be in a legal position to trade renewable energy with the national grid. The Feed in Tariff and Renewable Heat Incentive - alongside complementary policies such as the Green Deal 
- are very likely to encourage active participation from a range of 'new' actors (including households, cooperatives, housing associations or schools) in the energy generation market. The energy industry itself seems to have endorsed the view (at least rhetorically) that it needs to move beyond simply delivering energy commodities to providing energy in a way that reshapes not only the supply basis of the system, but is much more aligned to changes in scale, practice innovations, and more complex forms of decision making. In doing so, a relationship that has largely been based to date upon a pure commodity transaction between sellers and users must now be understood as a set of formal and informal partnerships among private companies (e.g. utilities and housing associations), public sector organizations (e.g. local authorities) and citizens.

\section{Results}

\subsection{Window of opportunity}

The ability to exert influence at a political level is fundamental to change. This is a key observation in conventional MLP literature where the regime is invariably posited as being fairly distinct from the niche level. The MLP perspective argues that change occurs when niche level practices are able consolidate and to develop in a way that is able to challenge and influence 'wider institutional changes' (Seyfang et al, 2014: 24). This article suggests however that local authorities provide an interesting case study to this proposition, particularly in the sense that some have been able to incorporate elements of both as vehicles for change; that is to say, some have been able to develop as niches, with their position as a part of the UK's political governing system offering a unique way to protect, incubate and disseminate innovative practices, technological insights and behavioural changes. This indicates that niche level innovations are not necessarily unique to civil society or more 'grassroots' activities (as much of the MLP literature in this area suggests), but that they can emerge from more formal institutions, in response to landscape pressures - in this case the influence of energy, environment and sustainability issues.

The interview data in this section reflects a range of views on the extent to which interviewees working for local authorities felt that there was a recognizable 'window of opportunity' opening up for them at a political level; enough to be in a position to exert greater influence on the current UK energy regime. The more recent policy landscape in the UK - including the publication this year of the Community Energy Strategy (DECC, 2014) - strongly indicates that there is recognition from the UK Government of a larger role for local authorities to play in coordinating a more sustainable and resilient energy system at the local level. The majority of interviewees in this research suggested that there was greater political influence emerging around the role of local government, although it was stressed that a measure of caution should be exercised in relation to some of the more far-reaching claims made for the extent of this influence. Interviewees stressed that there still remains still a large degree of centralization in key areas of practice, influence and decision-making in the current energy system. Whilst some agreed that there had been a shift towards greater local government influence around different aspects of energy, it was suggested that this remains rather disjointed, with no clear picture emerging around how these roles and responsibilities might emerge as a more coherent feature of, for instance, policy development and a consistent energy pathway being driven from local government level. 
It was pointed out by many interviewees that the increasing relevance of energy to a whole range of other issues in the UK - notably fuel poverty, transport, and planning - suggests that some kind of input to energy policy has become an almost unavoidable reality for local authority decision makers. As this interviewee from Oxford City Council argued: '...given climate change, given the increasing prices of energy, governments and international agencies have taken action about trying to curb the use of energy and switch to renewables and that we actually work out in practical terms what that means at a local level' (Oxford City Council). The issue of climate change was also raised by this interviewee from the same local authority: '...well as far as Oxford City Council is concerned, we see climate change as absolutely central, and saving money on energy use and so on, so that we've got four or five priorities for the council; housing is another, tackling fuel poverty and so on...but climate change is one of those and has been now for two years and so it affects everything we do' (Oxford City Council). The ways in which energy security issues have now become a local level concern was raised by this interviewee from Woking Borough Council, who argued: '...I guess we've seen some recent peaks in fossil fuel prices and energy costs so it's certainly brings it to the authority's attention and probably to members of the public's attention. When I started here I felt that the council's energy agenda was kind of a bit of a bold step which was quite possibly not going with the grain of energy policy or direction in the country. But now I feel it's something that other authorities are going to be considering, and is an important consideration for the UK as a whole' (Woking Borough Council).

The interviewee from Woking Borough Council, suggested that landscape issues regarding energy and environmental pressures, have created a 'window of opportunity' for local government to influence wider, societal change, '...beyond the introduction of a few wind turbines and solar panels', in a way that they would not previously have been in a position to do. He argued that some local authorities have been able to exert wider influence on the UK's energy agenda in a civic governance capacity; leading and developing flagship ways of doing energy and environmental policy. He pointed out that, whilst Woking has been able to develop effective technological projects - notably a combined heat and power plant which runs the local government offices and some of the surrounding offices in the area - these developments have also influenced the wider community. He made the particular point that '...local authorities have changed from being 'doers' in certain areas to being 'enablers'. Generally, councils overall have stepped away from a lot of hands-on stuff but nevertheless we do have a growing role in leadership and therefore, in this whole area, it's going to do what we can to help business but particularly residents, make it easy for them, to do the right thing in relation to energy (Woking Borough Council).'

Whilst most of the people who were interviewed recognized the significance of energy in offering local authorities more political leverage over some areas of policy, most were keen to point out that the emergence of these issues did not necessarily imply a leading role for them in governing the supply and demand of energy in the UK; in other words, influencing the UK's overarching energy regime in any significant way. One interviewee, who had worked with Surrey County Council, for example, was noticeably more reserved in relation to some of the more ambitious claims made for local authorities stepping into this kind of a leadership role. He observed that, originally, local authorities had a substantial role in governing the energy structure in the UK. However, he pointed out that the shift of post-war political economy towards firstly central government leadership, and then a market-led approach, had bequeathed a legacy of centralisation - effectively marginalizing their role as energy actors. He made the observation that this role had been reduced from quite a high profile position in UK 
energy governance, firstly by nationalization and the centralization of energy utilities, and then by market liberalization, where control had bypassed local government influence to the big energy companies. He reasoned that this had also been accompanied by an overall reduction in political status - primarily by the Conservative Government ethos around 'best value' based service provision which had characterized the $80 \mathrm{~s}$ and 90 s '...You've still got, I think, a very limited concept of what local authorities can do by way of energy governance even though the demand for them to do that has gone up. So, for example, there's been in the last 10 years a clear expectation that local authorities will do things about climate change... a clear expectation that they should have some kind of sustainable development vision...and they are also meant to be brokers of local consensus between cross-sectors through local strategic partnerships and the local area agreement' (Surrey County Council).

Most of the interviewees in this section argued that local authorities have become more active in influencing 'energy governance' in the UK in more recent years. It was argued that the influence of issues such as climate change and energy security means that there has been little alternative but to respond to these issues in some way at the level of local governance. It was suggested however, that this has not been a uniform response. It was recognized that, whilst some local authorities have been able to exploit their overall position in the UK governing regime, and have been able to exert political influence over say, renewable energy possibilities in the area, or maybe civic leadership over local climate change agendas, many still don't 'do' energy for its own sake. It was argued that, where they have become more involved in energy decision making, it has generally been as a means through which to deliver on other objectives, such as fuel poverty for instance. Therefore, whilst some have taken the lead on energy and/or environmental issues, this is by no means the case with all local authorities. It was suggested by the interviewee from Surrey County Council for instance, that one of the reasons for this current 'ambiguity' around the role of local authorities in energy governance might be linked to the historical influence of changing socio-technological systems in the UK, whereby they went from being influential energy regime actors in more localized systems of provision, to peripheral actors in a largely centralized energy system. It was suggested that is this dialectic is still being played out, whereby some have responded to energy and environmental issues as 'political agents', whilst others have simply responded in a de facto way.

\subsection{Community Engagement}

It has been suggested that the links between institutions, communities and individuals are critical in carving out more sustainable pathways (see for example Roberts, 2010 and Peters et al, 2010). As Walker et al. (2010:24) point out: 'local, collective activity has been cast as the site at which action can be the most effective, most appropriate and most lasting in generating change through empowerment of ordinary people and communities to act collectively for a better future'. Local authorities can be important agencies in catalyzing this level of change. Reflecting this view, all of the interviewees in this research agreed that engaging with the public is a critical aspect of developing an effective vision around sustainability at the local level, and there were two broad themes in relation to this which arose from the interviews. In the first theme, responses focused on particular initiatives developed by the local authorities where involvement of the community has played a central role. The second theme developed in this paper therefore includes responses that referred to the broader, strategic aims of local government in combining democratic and institutional renewal towards a more sustainable future. As would be expected, local authority agendas around community engagement vary in 
aims and scope. In Tables 1 and 2 the characteristics of two local authority energy/climate change projects are described, both of which were set up to encourage wider links with the community in Oxford and Bradford respectively.

Table 1: Outline details of Oxford City Council's 'Low Carbon Oxford' initiative

\begin{tabular}{|c|c|}
\hline Name of initiative & Low Carbon Oxford \\
\hline Operator & Oxford City Council/Oxford Strategic Partnership \\
\hline Brief details & $\begin{array}{l}\text { A city-wide programme of collaboration between private, public and non- } \\
\text { profit organisations with the aim of ensuring Oxford's future as a } \\
\text { sustainable and low carbon city. }\end{array}$ \\
\hline Date established & $\begin{array}{l}\text { Led by the Oxford Strategic Partnership, the Low Carbon Oxford programme } \\
\text { was launched on } 14 \text { October } 2010 \text { when } 15 \text { Pathfinder organisations signed } \\
\text { the Low Carbon Oxford Charter }\end{array}$ \\
\hline Status & On-going \\
\hline Main objectives & $\begin{array}{l}\text { - to reduce the overall carbon emissions of the city by } 3 \% \text { year } \\
\text { on year - achieving an } 80 \% \text { reduction by } 2050 \text {, } \\
\text { - the creation of more 'green jobs' and a sustainable economy, } \\
\text { - for Oxford to become an exemplar low carbon city for the UK }\end{array}$ \\
\hline Progress & $\begin{array}{l}\text { The programme is rapidly gathering momentum; there are now } 23 \\
\text { pathfinder organisations committed to the charter. The programme has } 3 \\
\text { key strands: } \\
\text { Pathfinder Programme: A set of collaboration projects which Pathfinder } \\
\text { organisations from the public sector, private sector and the community will } \\
\text { work together to develop and which will lead to short-term impacts on } \\
\text { carbon emissions. } \\
\text { Measuring, Monitoring and Mapping: Academics and experts in field of } \\
\text { carbon footprinting collaborating to develop standard methodologies for } \\
\text { measuring and monitoring of carbon footprint and emissions of } \\
\text { organisations and individuals in Oxford and for mapping an overall carbon } \\
\text { footprint for the city. } \\
\text { Oxford Futures: In order to tackle the problem of climate change and adapt } \\
\text { for future conditions some large scale forward thinking is required. Oxford } \\
\text { Futures is the arm of the programme which is concerned with cutting edge } \\
\text { technologies and large scale solutions for the sustainability of the whole } \\
\text { city; working with universities and researchers to reach } 2050 \text { targets as soon } \\
\text { as possible. }\end{array}$ \\
\hline Economic dimensions & $\begin{array}{l}\text { Since its inception the programme has attracted over } f 300,000 \text { in funding } \\
\text { and there are a number of projects in place which aim to contribute to } \\
\text { carbon reduction across the city. }\end{array}$ \\
\hline Social aspects & $\begin{array}{l}\text { There is a strand of the programme entitled 'Low Carbon Oxford for } \\
\text { Communities and Individuals' within which the OxCO2 project is located. } \\
\text { This project is developing a structured approach to community action on } \\
\text { climate change across the City of Oxford. The project is funding the } \\
\text { development of city-wide social enterprises, a low carbon communities } \\
\text { toolkit and } 3 \text { pilot communities. A suite of mentoring and training packages } \\
\text { are being developed to support new low carbon communities to get going. } \\
\text { The replication of this approach will be tested in } 3 \text { communities across } \\
\text { Oxford: Low Carbon Oxford North, an affluent community already active; } \\
\text { Barton, a deprived community with no activity; and Low Carbon South }\end{array}$ \\
\hline
\end{tabular}


Oxford, a mixed community struggling to get going. Around $20 \%$ of the City will be covered in the pilot programme and it is expected that the project will be self-sustaining until at least 2050 .

Table 2: Outline details of Bradford District Council's 'Community Warmth' initiative

\begin{tabular}{|c|c|}
\hline Name of initiative & Community Warmth \\
\hline Operator & Bradford Metropolitan District Council (BDC) \\
\hline Brief details & $\begin{array}{l}\text { BDC worked in partnership with NPower to offer free loft and cavity wall } \\
\text { insulation to residents over } 60 \text { and those in receipt of certain benefits. In } \\
\text { addition, all private sector residents could benefit from the scheme by } \\
\text { receiving heavily subsidized insulation even if they did not qualify for free } \\
\text { work. }\end{array}$ \\
\hline Date established & September 2008 - March 2011 \\
\hline Status & The initiative has ended \\
\hline Main objectives & $\begin{array}{l}\text { The scheme offered a free home energy service by a qualified } \\
\text { surveyor, who also asked residents if they had fuel payment } \\
\text { problems or if they would like a benefit entitlement check. } \\
\text { Residents were also referred to the Fire Service for a free smoke } \\
\text { detector (if they did not have a working one), and every household } \\
\text { surveyed received two free energy-saving light bulbs. }\end{array}$ \\
\hline $\begin{array}{l}\text { Progress/Forms of } \\
\text { technology involved }\end{array}$ & $\begin{array}{l}\text { - Work at each property was carried out by Community Warmth's } \\
\text { specialist team of contractors, usually being completed in less than } \\
\text { a day. } \\
\text { Bradford has polarised wealth distribution. Measures were moved } \\
\text { round so that all areas had opportunity to benefit. The scheme was } \\
\text { successful in relation to carbon saving and also in addressing the } \\
\text { fuel poverty and health agenda. }\end{array}$ \\
\hline Economic dimensions & $\begin{array}{l}\text { The project was financed as a partnership effort between the council and } \\
\text { NPower. }\end{array}$ \\
\hline Social aspects & $\begin{array}{l}\text { An N Power brand, working with community groups. The BCC side of the } \\
\text { partnership demonstrates the value of local authorities - local people 'tend } \\
\text { to trust the local authority because we're not making a profit and if you're } \\
\text { not happy you can complain'. }\end{array}$ \\
\hline
\end{tabular}

Local authority projects which have been designed to engage community members, as outlined by the interviewees who took part in this research, were broadly indicative of initiatives developed both by both local government and community groups over the last 5-10 years, which have been aimed at encouraging the realization of sustainable energy solutions and shifts to lower carbon lifestyles. Amongst the benefits for local authority action in this area, one interviewee highlighted the ways in which '...local people are just very keen to get involved and to do something, and we're encouraging that' (Oxford City Council). For another interviewee engaging communities is about raising awareness, particularly around environmental issues: '....without those relationships at the local level there is no energy ecology. Part of it is a lot of those relationships tend to be based on certain agendas, or on certain parameters, so the challenge then is to possibly look at the multitude of relationships that we've currently got. Just about every one of our customers/citizens is an energy user' (Bradford City Council). The following interviewee highlighted the importance of linking community engagement in with the 
existing national policy framework and objectives, such as the Green Deal: '...it's more the networks we can tap into that are not carbon related that will help us to deliver something like the Green Deal. So that will help us to engage with bits of the community who wouldn't ever, who will never, get switched onto to carbon, but actually who could benefit from something like the Green Deal' (Oxford City Council).

As well as demonstrating several opportunities and benefits associated with these endeavors (including the provision of resources: education, information, advice, physical and cognitive space; and pointers to practical action), many of the interviewees touched on issues that resonate with growing evidence around the barriers facing community-oriented energy/climate change initiatives, particularly in relation to engagement. The primary obstacles are well known, relating to the difficulty of generating interest and participation beyond those already routinely engaged in 'pro-environmental' behaviours and with an existing interest in sustainability issues. There was a general perception that the problem of connecting political institutions with society more broadly remains a persistent challenge. Interviewees argued that, almost inevitably, making this connection requires some recognition of difference and diversity among individuals of the same community. It was pointed out that defining the term 'community' can itself be problematic as society is decreasingly made up of discrete, geographically identifiable communities and is increasingly composed of many diverse communities, which often overlap and at times exist in complete isolation from one another (for a full treatment of this issue see Peters et al, 2010).

While it was felt by all interviewees that local authorities have an important role to play in connecting communities with their role in the longer-term UK energy transition, there was a sense that persistent barriers to engagement between the two remain symptomatic of broader problems associated with formal political institutions; in this case as change agents in addressing the more intractable challenges associated with sustainable development (Byrne, 2000; Fudge and Peters, 2009). There was a sense from interviewees that local authorities - particularly those in Oxford City Council - who were attempting encourage niche activities around engaging people in the environmental agenda, or encouraging sustainable behaviour in their surrounding communities, were doing their best to overturn, often particular community perceptions of them; namely an invariably negative image of them as a part of the UK's governing regime, where associated problems of low levels of political trust and a lack of confidence in (local) government policies often serve to impede the efficiency and successfulness of locally focused initiatives these areas. However, as Seyfang et al. (2014: 26) observe in relation to the role of more grassroots endeavors in this area: 'some groups and initiatives aim only to solve local problems - these we call 'simple projects as opposed to 'strategic' projects which aim to have wider influence'. It is important to bear in mind here the relevance and relationship between scale of impact/scope of activities with short and longer term (i.e. timescale) objectives. This is evidenced by the activities of some local authorities that have been more motivated to develop a longer-term strategy of engaging with their local communities - and others who have not prioritized such an approach as part of their long-term 'visions' for sustainable development.

\subsection{Technology and technological innovation}

Observers such as Smith et al. (2013) suggest that, as well as engaging in experimentation with local partnerships and models of behaviour change and community action, the changing policy landscape around energy in the UK also offers the chance for local authorities to act as niche sites for more technologically driven pathways to sustainability. Whilst so far being fairly 
embryonic, this kind of emerging 'governing actors' network in energy supply and generation can, in fact, be observed in several local authority areas including Woking, Kirklees, Gateshead, Milton Keynes, and Leicester. Here local councils have begun to initiate and develop a number of decentralized forms of energy distribution and supply, demonstrating workable and potential alternatives to the UK's traditionally centralized energy supply infrastructure. Whilst these developments remain the exception rather than the rule, there is no doubt that, spurred on by emerging changes in the use and conceptualisation of energy as well as the planning changes outlined in the previous section, the likelihood is that local authorities will be expected to become more engaged in the technological aspects of the UK's shift towards a low carbon energy infrastructure in the coming years.

This interviewee from Bradford City Council highlighted some of the niche possibilities through which local government might be able to exert an increasing measure of influence over infrastructural change and geographical areas through which to nurture or prime technological innovations. As he argued, identifying and encouraging local knowledge, 'what works best', and wrapping these around a longer term vision, were important to the success of this process: '...there are [technological] initiatives yes, we can point to activities, yes, we can point to new boiler systems and new ways of monitoring our energy internally and some of the conversations we're now having inside the district. But there's something for me about how we're trying to move away from initiatives and activity to have a much better sense from a systems point of view' (Bradford District Council).

He made the point that, in his view, local authorities are probably the best placed local organizations to pull together and coordinate such expertise at a practical level of implementation. Whether this directly involves communities, businesses or architects for example, it was argued that local authorities are well positioned to decide and implement the most appropriate sustainability strategy for the particular conditions and circumstances that exist in that area. He provided an illustration of the particular situation in Bradford: 'As one of the largest geographical areas of a local authority of anywhere in England, we get a whole load of solar radiation coming into this district. But, at the moment, we've got no understanding about what the solar potential is for Bradford, how that solar potential could be harnessed with current technology, or how that solar potential is already harnessed by plants, animals and human beings...because we are then trapped by conventional thinking about energy systems (Bradford District Council). As he argued, there exist many complexities around implementing effective sustainability initiatives in local authority areas which are often very different from place to place in terms of geography, population, resources, levels of capacity, and internal cohesion around policy aims and objectives. This means that ultimately appropriate strategies for technology choice can only be successful if they are led from the local level.

In Surrey, the County Council's programme of sustainable energy technology was originally developed in relation to the Council's problem with waste management. This interviewee from Surrey County Council suggested that energy itself had almost been incidental to the County's waste management strategy, but that the council's approach to converting waste destined for landfill into useable energy via anaerobic digestion, had made energy a commercially viable commodity, helping to enable the degree of consensus necessary to push the programme forward. He argued that, in the end, Surrey County Council used a pragmatic approach to sustainability which was driven by a number of different influences. The technological emphasis itself came out of the process by which the County Council decided that they were going to 
address sustainability in the area - a problem which needed to be solved by trying to develop a more innovative way of dealing with their waste problem: 'We had a huge problem with landfill. You could either sit there and get fined for sending waste to landfill or you could increase the recycling rate, which we did up to a $60 \%$ target. And the quid pro quo for that is that we would have to accept energy from waste caps of $40 \%$ of the non-recycled waste. So that was quite a good strategy overall. And we calculated that we'd be able to provide electricity for something like 20,000 households from this plant, maybe also do domestic heating from the waste heat. So, that was the top down bit of energy governance' (Surrey County Council).

As outlined in this section, the changing policy landscape around energy in the UK has offered the chance for some local authorities to evolve as niches around technologically driven solutions and Birmingham, Kirklees, Southampton and Leicestershire have been amongst those who have been central actors in developing renewable and distributed energy generation in their particular areas. In terms of the participating local authorities in the current study, Woking Borough Council stands out as the most observable example of technological leadership in energy supply and generation. Over several years the council has established a range of distributed forms of energy generation and supply in attempts to demonstrate the practicality and potential of these alternatives to the UK's traditionally centralized energy infrastructure. As with findings in the preceding sections, local authorities who have followed this pathway remain the exception rather than the rule.

\section{Discussion and concluding remarks}

It is argued in this paper that local authorities in the UK present an interesting and productive way in which to explore the 'system boundaries' dilemma which characterises the Multi-Level Perspective literature on sustainable energy transitions. It was suggested earlier that this paper provides a contribution to this discussion by considering how the transition to a low carbon economy has opened up possibilities for local authorities in the UK to become more influential in driving 'energy governance' from the local level. The paper argues that the role of local authorities in the UK has highlighted some interesting dynamics around creativity, innovation and influence over different aspects of the low carbon agenda, some of which suggests a more complex relationship in conventional understandings of the relationship between niche and regime levels in the MLP literature. Drawing on qualitative data gathered during interviews with six local authorities in the UK, it was pointed out that there is a diversity of approaches towards energy and environmental issues with some of these actions being more obviously organized around technological approaches - including those which have branched into local energy generation initiatives - whilst others have adopted more social/cultural approaches, where the intention has been to try to engage and influence the behaviours and practices of individuals and communities. Still other approaches have attempted to develop combinations of the two approaches, reflecting the complex nature of emerging models of energy governance. Other local authorities have yet to provide any real influence in these areas at all.

As outlined at the beginning of the paper, in the UK the role of local authorities in a sustainable energy transition has been recognized - at least in rhetoric - by the UK Government. For example, the potential for local authorities to play a larger role in contributing to and developing UK energy policy towards a more sustainable pathway, is a recognizable element of the Low Carbon Transition Plan (DECC, 2009), the 2011 UK Carbon Plan (HM Government, 2011), and the more recent Community Consultation (2014). As highlighted here, as energy and environmental issues have taken on greater prominence in both national and international level policy making, 
so the role of local authorities - and community-led approaches to sustainability - have emerged as viable ways through which to engage with both the technological aspects of energy generation, and also with respect to the delivery of sustainable demand-side energy management strategies. This is notable not only in the UK but also in several countries across Europe. For example, in Finland, a historical legacy of bottom-up policies has been a principal driver of the current energy system, where renewable sources account for almost 30 percent of all primary energy consumed. Similarly, in Germany, the more recent emphasis on stakeholder engagement (as exemplified, for example, by the Solar City concept pioneered in Freiburg) has paved the way for a coordinated market economy approach to the development of a suite of renewable technologies.

Much of the interview data in this paper corroborates the views of Roberts (2010), who argues that in order for local authorities per se to become more influential players in governing and influencing energy policy in the UK, such a role will derive principally from developing and enhancing the services that they already deliver; the strategic roles they currently play; and the regulatory influence they have to enforce national standards and directives. In the MLP literature, regimes are defined in part as the ways, means and skills through which society is organized. In this way, some interviewees felt that a significant barrier to a higher profile for local government in influencing the energy agenda in the UK is that many local authorities currently lack specific knowledge of the energy sector, and therefore the skills necessary to engage effectively with the agenda. For instance, the emergence of new structures and institutions including the enhanced role of Energy Service Companies (ESCOs), demands knowledge and capacity to collaborate between energy suppliers, planners, property holders, community groups, financial services and the construction sector. The emergence of this new 'energy service sector' in the UK could, in theory, allow local authorities to engage more fully with the process of shaping and influencing the socio-technical systems around, for instance, the potential for the establishment of more distributed forms of energy production, and the accompanying process of enabling citizen-consumers to understand more fully the consequences of their energy choices and their end use decisions. However, interviewees who raised this issue felt that such a shift would demand that appropriate and sustainable engagement structures are negotiated in order to provide meaningful opportunities for community involvement, with suitable connections to energy providers, funders, regulators, and other communities of practice. It was suggested that this raises questions about who should create and maintain these structures and also how they should be regulated at a political level. To this end, the interviewee from Surrey County Council suggested that part of the reason for local authorities' relative lack of political influence over energy and environmental issues is that national government aims and objectives retain primary influence over proceedings in the last instance. This interviewee also argued that a lack of clear guidelines from the higher levels of governance has resulted in a lack of consistency in national-led policy making on energy, which then filters down to local government level. All interviewees were very clear that local authorities should have a role to play in developing and guiding energy policy at action at the local level but it was suggested that, in addition to the need for some form of subsidiarity, there was currently little incentive for the majority of local actors to risk leadership or to pursue first mover status whilst budgets are being cut and priorities remain fixed on ensuring economic growth - often at the expense of climate and environmental targets.

It was clear from much of the interview data that these issues continue to pose challenges for local authorities in leading on more localized forms of energy governance. It was argued that 
many local authorities are currently struggling with shrinking resources, growing social needs and face significant challenges in balancing priorities. Within the wider community, many of them are also struggling to grapple with the practical factors that can prevent individuals especially the most vulnerable and disadvantaged - from participating in community decisionmaking. In this way, it was argued that whilst local authorities would seem to be ideally situated to encourage a broader transition around energy and environmental goals which is driven from the local level, there is currently a lack of appropriate structures in place to provide meaningful opportunities for real influence, particularly in relation to effective connections to energy providers, funders, regulators, planners and other communities of practice. There was a sense from the interviewees in this research that, rather than having more influence on the currently existing energy regime, local authorities in many instances play an 'intermediary' role; for instance in translating or interpreting national (and beyond) policy down to the local level rather than in driving the agenda itself.

The interviewees from both Woking and Surrey felt that one of the main problems for local authorities in influencing the energy agenda in a more significant way, relates to a lack of clarity over whether they are now seen as 'doers' or 'enablers' in energy. It was pointed out that, traditionally, the role of local government in energy has been structured around enabling and providing services rather than leading on the development and delivery of energy policy. It was felt that there is confusion over leadership and responsibilities - a possible legacy of previous top-down policy approaches to energy in the UK. To this end it seems reasonable to argue that local authorities themselves hold a degree of uncertainty with regard to the ability of the current localism agenda to enable them to influence energy and environmental issues in any significant way.

The interview data considered in this paper certainly points to the potential benefits of augmented local authority led governance of energy and carbon, as well as demonstrating the possibilities for local institutions to act as catalysts or 'change agents' in exerting greater influence on sustainability transitions. As this paper suggests, energy and environmental issues have often caused local authorities to represent a certain level of ambiguity vis-à-vis their potential role as 'regime' actors. As Raven et al. (2012: 67) point out, in the MLP literature: 'the regime level is represented as endogenous structures enacted by extensive organizational networks and embedded in institutions and infrastructures that orient (constrains and enables) actor's behaviour. Regimes provide actors with heuristics or routines'. We suggest that whilst local authorities have, to date, largely been regime actors (with heuristics and routines which are often influenced, at least to a degree, by what Mitchell (2008) describes as the 'regulatory state paradigm'), this has never been a clear-cut relationship - particularly in energy policy. As argued in this paper, the history of socio-technical transitions in respect of energy policy in the UK has highlighted a certain ambiguity around the role of local authorities particularly with regard to their central and more peripheral roles in the overarching energy regime. It is posited that landscape challenges around climate change and energy security have in many ways offered a chance for some local authorities to challenge the dominant regime and to become more active players in energy governance. Thus far, however, this has largely been a piecemeal process, whereby some authorities have been more clearly motivated both to view and act on this 'window of opportunity' than others. In fact, the agency of local authorities, or willingness to act, was viewed as a key driver in this energy governance role, where some are more willing, for example to develop as niches in certain areas, whereas for others, energy and environmental issues are viewed, either as more of an extension to existing energy service provision, or not as a 
priority at all. Interviewees noted therefore that, rather than constituting an overall shift in the role of local governance on energy in the UK, influence, change and agency at this level have, up to now, largely been driven by a few forward thinking local government institutions or 'first movers'. This suggests that, whilst the role of local authorities has been changing in response to energy and environmental 'landscape' issues, their influence on the design and implementation of energy policy in the UK will correspondingly remain as an emerging process for the foreseeable future, with the more progressive local authorities continuing to exert political, social/cultural and technological influence over ways of designing, articulating, and engaging with energy governance at the local level.

\section{Acknowledgements}

The authors would like to thank Professor Tim Dixon (School of Construction Management and Engineering, University of Reading and Miles Ten Brink from the University of Manchester for their helpful insights and feedback on earlier drafts of this paper.

The support of the UK Natural Environment Research Council (NERC) is also gratefully acknowledged. Data drawn from the project described in this paper entitled "Understanding Local and Community Governance of Energy" (UNLOC) was funded through a grant provided by NERC via the UK Energy Research Council (UKERC).

\section{References}

Bolton, R., Foxon, T.J., 2013. Urban infrastructure dynamics: market regulation

and the shaping of district energy in UK cities, Environ. and Plan. A. 45, 2194-2211.

Byrne, T.,2000. Local Government in Britain: Everyone's Guide to How it all Works, seventh ed. Penguin, London.

Bulkeley, H., Castan-Broto, V., Maassen A., 2011. Governing urban low carbon transitions, in: Bulkeley, H., Castan-Broto, V., Hodson, M., Marvin, S., (Eds.), Cities and Low Carbon Transitions, Routledge, New York, pp. 29-41.

Bulkeley, H., Kern, L., 2006. Local government and climate change governance in the UK and Germany. Urb. Studies. 43, 2237-2259.

Calvert, K., Mabee, W., 2014. Energy Transition Management as a 'spatial strategy'? Geographical implications of the transition towards Renewable Energy. Queen's Institute for Energy and Environmental Policy, Working Paper. Available at: http://www.geog.psu.edu/sites/default/files/Calvert Geogs\%20of\%20RE working\%20paper.pdf (accessed 17/02/2014)

CCC., 2012. How Local Authorities can Reduce Emissions and manage Climate Change. Committee on Climate Change, London. Available at: http://www.theccc.org.uk/publication/how-local-authorities-can-reduce-emissions-andmanage-climate-risks/ (accessed 05/05/2014) 
CCC., 2013. Meeting Carbon Budgets, 2013 Progress Report to Parliament. Committee on Climate Change, London. Available at: http://www.theccc.org.uk/publication/2013-progressreport/ (accessed 29/10/2013)

DECC., 2009. The UK Low Carbon Transition Plan: National Strategy for Energy and Climate Change. Department of Energy and Climate Change.

Devine-Wright, P. (Ed.), 2011. Renewable Energy and the Public: from NIMBY to Participation. Earthscan, London.

Dixon, T., Wilson, E., 2013. Cities' low carbon plans in an 'age of austerity': an analysis of UK local authority actions, attitudes and responses. Carbon Mgt., 4(6), 1-17.

Fudge, S., Peters, M., 2009. Motivating carbon reduction in the UK: the role of local government as an agent of social change. J. Integrative Environ. Sci. 6(2), 103-120.

Fudge, S., Peters, M., Wade, J., 2012. Locating the Agency and Influence of Local Authorities in UK Energy Governance. University of Surrey, Centre for Environmental Strategy, Working Paper 01/12. Available at: http://www.surrey.ac.uk/ces/files/pdf/01-

12 Paper Fudge Peters Wade.pdf (accessed 06/01/2014)

Fudge, S., Peters, M., Hoffman, S., Wehrmeyer, W., (Eds.), 2013. The Global Challenge of Sustainable Living: Opportunities, Barriers, Policy and Practice. Edward Elgar Ltd., Cheltenham.

Geels, F.W., 2002. Technological transitions as evolutionary reconfiguration processes: a multilevel perspective and a case-study. Res. Pol., 31, 1257-1274.

Geels, F., 2010. Ontologies, socio-technical transitions (to sustainability), and the multi-level perspective. Res. Pol., 39(4), 495-510.

Haxeltine, A., Seyfang, G., 2009. Transitions for the People: Theory and practice of 'Transition' and 'Resilience' in UK's Transition Movement. Tyndall Centre for Climate Change Research, Norwich. Working Paper 134. Available at: http://www.tyndall.ac.uk/sites/default/files/twp134.pdf (accessed 14/02/2014)

HM Government, 2011. The Carbon Plan: Delivering our low carbon future. Department of Energy and Climate Change, London.

Hodson, M., Marvin, S., 2010. Mediating Low-Carbon Urban Transitions? Forms of Organization, Knowledge and Action. Eur. Plan. Studies. 20, 421-439.

IPCC, 2013. Climate Change 2013: The Physical Science Basis. Intergovernmental Panel on Climate Change Fifth Assessment Report. Geneva, Switzerland. Available at: http://www.ipcc.ch/ (accessed 15/10/2013).

Jackson, T., 2005. Motivating Sustainable Consumption: a review of evidence on consumer behaviour and behavioural change. Report to the Sustainable Development Research Network, January 2005. 
Loorbach, D., 2007. Transition Management: New Mode of Governance for Sustainable Development. International Books, Utrecht.

McGuirk, P., Dowling, R., Brennan, C., Bulkeley, H., 2015. Urban carbon governance experiments: the role of Australian local governments. Geog. Res. 53, 39-52.

Mitchell, C., 2008. The Political Economy of Sustainable Energy. Palgrave Macmillan, London.

Mulugetta, Y., Jackson, T., van der Horst D., 2010. Carbon Reduction at Community Scale. Energy Pol., 38, $7541-7545$.

Peters, M., Fudge, S., Jackson, T., (Eds.), 2010. Low carbon communities: imaginative approaches to combating climate change locally. Edward Elgar Ltd., Cheltenham.

Peters, M., Fudge, S., Hoffman, S.M., 2013. The persistent challenge of encouraging public participation in the low carbon transition. Carbon Mgt., 4(4), 373-375.

Raven, R., Schot, J., Berkhout, F., 2012. Space and Scale in Socio-Technical Transitions. Env. Innov. and Soc. Transitions., 4, 63-78.

Roberts, S., 2010. The Role of local authorities in galvanizing action to tackle climate change: a practitioner's perspective. In Peters, M., Fudge, S., Jackson, T., (Eds.), Low Carbon Communities: Imaginative Approaches to Combatting Climate Change Locally. Edward Elgar Ltd., Cheltenham, pp. 75-88.

Royal Commission, 2000. Report on Environmental Pollution. The Royal Commission on Environmental Pollution. Available at:

http://webarchive.nationalarchives.gov.uk/20110322143804/http://www.rcep.org.uk/index.ht m (accessed 23/07/2014)

Scrace, I., MacKerron, G., (Eds.), 2009. Energy for the Future: A New Agenda. Palgrave Macmillan, London.

Smith, A., Kern, F., Raven, R., Verhees, B., 2013. Spaces for Sustainable Innovation: Solar Photovoltaic Electricity in the UK. Tech. Forecasting and Chg. 81, 115-130.

Späth, P., Rohracher, H., 2010. 'Energy Regions': The transformative power of regional discourses on socio-technical futures. Res. Pol. 39(4), 449-458.

Unruh, G. C., 2000. Understanding carbon lock-in. Energy Pol. 28, 817-83.

Wade, J., 2008. Taking the lead - local authorities and the climate change agenda. In Sinn, C., Perry, J., (Eds.), Housing, the Environment and Our Changing Climate. Chartered Institute of Housing, Coventry, UK.

Walker, G., Devine-Wright, P., 2008. Community renewable energy: what should it mean? Energy Pol. 36, 497-500. 
Walker, G., Devine-Wright, P., Hunter, S., High, H., Evans, B., 2010. Trust and community: exploring the meanings, contexts and dynamics of community renewable energy. Energy Pol. 38, 2655-2663.

Table 1: Details of interview participants

\begin{tabular}{|c|c|}
\hline Local Authority & Position of interviewee \\
\hline Surrey County Council & Senior policy adviser (energy and waste) \\
\hline Bradford District Council & Strategy Coordinator - Sustainability \\
\hline Bradford District Council & Environment and Climate Change Manager \\
\hline Bradford District Council & Sustainable housing team officer \\
\hline Bradford District Council & Sustainable housing team officer \\
\hline Bradford District Council & Team Leader Local Development Framework \\
\hline Bradford District Council & Local Development Framework team - officer \\
\hline Woking Borough Council & Energy Services Company - Group Managing Director \\
\hline Woking Borough Council & Energy Services Company - Operations Manager \\
\hline Woking Borough Council & Strategic Director \\
\hline Woking Borough Council & Senior Policy Officer \\
\hline Oxford City Council & Environmental Sustainability Manager \\
\hline Oxford City Council & Energy and Climate Team Leader \\
\hline Oxford City Council & City Development Director \\
\hline Oxford City Council & City Councillor, Cabinet Member \\
\hline Rhondda Cynon Taff County Borough Council & Resilience \& Sustainability Manager \\
\hline Rhondda Cynon Taff County Borough Council & Resilience \& Sustainability Manager \\
\hline Kirklees District Council & Sustainability Officer \\
\hline Energy Saving Trust & Senior energy advisor \\
\hline
\end{tabular}

